\title{
An East-West Encounter in Underground Man: Harmony in Gabriel Tarde and in Chinese Philosophy
}

\author{
Gürhan Kirilen \\ Ankara University, Ankara, Turkey
}

French philosopher Gabriel Tarde is known as a philosopher who describes sociology ontologically with an integrated approach and mostly by means of metaphysical interpretations. Opposing his coeval Durkheim's "social fact", Tarde claims that this notion constitutes a methodological problem and the term "social" of Durkheim's crowds out "variability of relations". According to him, determinants in social relations are more general and dynamic notions, such as: "change", "contrast", and "adaptation”. In this respect, not quite celebrated in his era, this philosopher is widely known as a metaphysician as well as a sociologist. His metaphysical ideas are clearly visible in various sections of his works, where he described with inspirations from natural phenomenon. Descriptions and analysis on natural phenomena constitute the greater part of his works. He points out similarities between the universe and the world of men in terms of functioning. Presenting these similarities, Tarde seems to reject any division between the men and the nature built up by "positive philosophy" and modern understanding. With his natural descriptions and concepts he inferred from these descriptions, such as "contradiction" and "harmony", he almost tries to re-establish the bonds between the nature and the social life. Tarde's perception of holistic being and his ideas of "contradiction" and "harmony" in nature, are very close to the most basic axioms of the traditional Chinese thought. As a matter of fact, Tarde denotes these similarities in his novella called "Fragment d'histoire future (Underground Man)". It is also an example to display an "East-West encounter" on a fictional plane.

Keywords: Utopia, Underground Man, harmony, adaptation, Chinese philosophy

\section{Introduction}

In Underground $\mathrm{Man}^{1}$ Tarde presents some manifestations of his notions on a fictional plane which he handles in his other works such as "Economic Psychology", "Monadology and Sociology", and "Social Laws". Underground Man, an example of fantastic fiction, is a dystopia as well as a salvation story. Whereas in most of classical Utopias a new order is envisioned beyond the sea or in the sky, Tarde tries to create it underground. This is why his Utopia ends darkly, though the life he fictionalizes is not dark at all.

In the story, by the end of 25th century, the Earth's life source, the Sun, consumes all its energy and begins to die. As the Sun has no power left to warm the Earth, the glaciers begin "walking" again and cover surface of the Earth for the last time. The sudden drop in the temperature causes mass deaths. Few people can take shelter in the equatorial areas. When it becomes evident that it's not possible to survive on the surface, a small number

Gürhan Kırilen, Assistant Professor, Dr., Ankara University.

1 The original name of the novella is "Fragment d'histoire future" but it's commonly known as "Underground Man" in English and it was also translated into Turkish with the title "Geleceğin Tarihinden Alıntılar" which is faithful to its original name. In this paper I preferred to use the English "Underground Man". 
of survivors helplessly migrate underground and plant the seeds of a new civilization. ${ }^{2}$

After the glacier catastrophe, a hero called Miltiades ${ }^{3}$ gathers the survivors and leads them. Miltiades is an ambitious leader and he moves people' hearts with a speech which Tarde narrates lengthily in an epic manner (Tarde, 1905,pp. 63-80). "The Earth calls us into its inner self!" Miltiades says (Tarde, 1905, p. 76) before they migrate to create a new life and establish their civilization on the partial legacy of the "olden culture", 4 which soon turns into a museum (Tarde, 1905, pp. 86, 88, 92). Despite various difficulties, the life here corporally and ideally forms a "closed system" and forces its people to become "humans" only. The hard conditions "underground" lead them to be free from their earlier "uncertain" natural environment. Here, there are neither animals, which share natural sources, nor challenging climates. After getting rid of "stimuli and incitation" of the surface, the only pursuit of human race is to cultivate itself.

In his Utopia Tarde describes a world where social people live with high-level adaptation ability. He portrays the harmonious unity of people living beneath the earth's crust:

...An indescribable courtesy, skilled to charm without falsehood, to please without obsequiousness, the most free from fawning one has ever seen, is united to a politeness which has at heart the feeling, not of a social hierarchy to be respected, but of a social harmony to be maintained...(Tarde, 1905,pp. 141-142)

Tarde's underground society is pure and indescribably noble. Instead of social hierarchy, its fabric is fascinating courtesy of social harmony. In accordance with Tarde's philosophical approach, life there is based on harmony and adaptation which combine social commitment with loyalty. For him, loyalty means faithfulness: faith to the underground community, to its success and to the idea of people's unity (Tarde, 1905,pp. 171-172). Social harmony, which is inevitable in a closed system ${ }^{5}$, is the only way for human race's survival. As the planet cools down, the "Underground Man" evolves into a well-balanced, compliant person and becomes more and more civilized in each layer, “...bale by bale into the bowels of the Earth” (Tarde,1905, p. 92).

As in all closed systems, this "underground life" cannot sustain continuous conflicts. Quite contrary to the "olden times" on the surface, here in the underground it's an obligation to maintain a peaceful atmosphere. Even so, the first immigrants"unconsciously" attempt to fight; but soon it is understood that "there is no mean between warfare and love" anymore (Tarde,1905,p. 105). Therefore, they turn towards the only way out, toward "love" which will help them survive. Before the ultimate peace, there occurs one last struggle between partisans of "passion" ${ }^{6}$ and "prudent love". This last fight ends up with the triumph of "prudent love" as

\footnotetext{
${ }^{2}$ When the Sun suddenly loses its power and begins to die, the temperature decreases rapidly on the Earth and millions of people freeze to death in a very short time. The glaciers that move from the poles begin to surround the entire world. The survivors take refuge in hot regions like Arabia. However, the Earth turns into an ice ball soon.

${ }^{3}$ Miltiades (550-489 BC) is a historical figure and the hero of Battle of Marathon. He had shown an outstanding leadership in Greek history. It seems like Tarde chose this name as a metaphorical connotation and a way to show his admiration to Greek culture.

${ }^{4}$ Before migrating to underground, people also carry samples of the most elegant artistic and technological products to underground. A lot of things such as old photos and umbrellaare displayed in the museums.

5 As it seems, Tarde was able to fictionalize such a harmonious community, which he believed that it could be established within a closed system, only by carrying this community underground. However, Tarde's community should not be considered to be closed at all. When the hysteria spreads in the whole community every year in May, the "lovers" throw themselves out to the surface. Tarde shows closed systems are possible. His main concern was sustainability which was connected to time flow and duration. His projection in the novella is a far reaching change and adaptation to the environment that enables the longest survival. ${ }^{6}$ Miltiades is one of the last supporters of "endless free love". The passionate love of this hero made millions of people gather around the "migration" idea. His passion again brought his own end: "Miltiades was misled by his passion and committed the fault..." (Tarde, 1905,p. 106).
} 
expected, and in the end, there is neither passion nor craziness left in underground. Then the "Underground Man" has become human in order to delight humanity and which humanity has deified in order to shelter love beneath its shade..." (Tarde, 1905, p. 129).

"In the bosom of their earth" as the time passes, the underground people conquer wider areas; by reconstructing the conquered places they create wonderful cities ornamented with diamonds and gold: “...Our dwelling-places, or of the cities; they are filled with heaps of artistic marvels, of frescoes, enamels, gold and silver plate bronzes and pictures..." (Tarde,1905, p. 134). These cities are like huge exhibition halls of a magnificent civilization, displaying glamorous scenes with colorful streets, squares, and residential areas (Tarde, 1905, pp. 132-135). Owing to the development of "subtle technology and complex methods", life in the underground shows much variety in that, by each stage, "the needs of the people were satisfied more completely" (Tarde 2000, p. 40). ${ }^{7}$

During one of the expeditions undertaken by the underground people, an unexpected encounter occurs in the abyss. Scientists run across to another civilization founded by Chinese in the depths of the Pacific Ocean:

...Beyond the ordinary galleries, suddenly penetrated into a strange open space buzzing with human voices and swarming with human faces... ...What squeaky voices! What sallow complexions! What an impossible language with no connection with ours! (Tarde, 1905, p. 156-157)

The Chinese are wild and barbarous to the extent of cannibalism, "instead of confining themselves as we to turning to account the deposits of animal carcasses, they had shamelessly given themselves up to ancestral cannibalism..." (Tarde, 1905, p. 157). Unlike Tarde's underground civilization, they are not satisfied with eating dead animals, and have begun to eat their ancestors without shame. Tarde's opinions about the Chinese are extremely unfavorable; he describes them as "unclean, rude, greedy and mean" (Tarde, 1905, p. 157). However, despite his negative judgment, Tarde dignifies their competence for adaptation and orientation. Apart from these two peoples, no other community could adapt to the difficulties of life in underground nor have any other attempted to survive. In this sense, Tarde grants the Chinese due smartness to overcome the challenges "of underground life" and for him, they were competent and even faster, he says "...Chinese had the same idea as our Miltiades. Much more practical than he, they hastily crawled underground..." (Tarde, 1905, p. 157). They immigrated before Miltiades arrives and their idea was much more practical than Miltiades'. Eventually, Chinese people have succeeded to settle on a broad area that spreads "as wide as America".

There are quite explicit differences between Tarde's underground community and Chinese people. While Tarde's people established a community on the refined legacy of their former civilization, the Chinese carried their simple life to underground "without encumbering themselves with museums or libraries" (Tarde, 1905, p. 157). There are neither plants nor animals in Tarde's civilization, but the Chinese grow vegetables in the pots and keep pets with heavy labor and expense. (Tarde, 1905, p. 158)

After the initial encounter, Tarde's underground civilization sends missionaries among the Chinese. They invite them to the "true way", and to become civilized. ${ }^{8}$ However, the Chinese go on their own way, and in

\footnotetext{
${ }^{7}$ Nutrition does not pose a problem because explorers are able to obtain food from the frozen herds on the Earth's surface and from the schools of fish in the frozen oceans. And chemistry reaches such a level that foods are provided from rocks and mineral storages. (Tarde,1905, pp. 81, 170)

8 "They laughed a lot when some of our scholars who were sent as attendants mentioned them about the celestial sphere, the sun, the moon and the stars. However, they were still listening to these stories to the very end and then they were asking to our missionaries: 'Well, have you ever seen all these things?' Unfortunately, our missionaries were not able to give an answer to this question.” (Tarde,1905, pp. 148-159)
} 
the end Tarde asks: “...what did our settlers do at the sight of such cerebral atrophy?” He answers,

Several proposed to exterminate these savages who might well become dangerous owing to their cunning and to their numbers, and to appropriate their dwelling-place after a certain amount of cleaning and painting and the removal of numerous little bells. Others proposed to reduce them to the status of slaves or servants in order to shift on to them all our menial work. But these two proposals were rejected. An attempt was made to civilize and to render less savage these poor cousins, and once the impossibility of any success in that direction had been ascertained the partition was carefully blocked up. (Tarde, 1905, p. 159)

With reference to this encounter, then, this paper aims to compare the concepts of "adaptation and harmony" in Tarde's thought with Chinese traditional notions of harmony he, yin-yang and $l i$.

\section{Gabriel Tarde’s Perception of Harmony}

Harmony for Tarde begins from the "monad", which is the smallest element of his philosophy. The monad is the first essence, a building block used for creating entities. He perceives monad to be a half-living essence with a sort of consciousness (Tarde, 2012, pp.17, 26, 27, 36, 55). The idea of conscious monad is based on two tendencies: "existing" and "possessing".He presumes that similar tendencies are present in all other entities (Tarde, 2012, p. 86). ${ }^{9}$ Quite different from Leibniz's monads, Tarde offers explicit and intertwining ones. He presumes them as living beings ${ }^{10}$ rather than being mutually external; he conceives open monads which would penetrate each other reciprocally (Tarde,2012, p. 26). He focuses on inter-monad relations more than their initial forms and he examines these relations on three determinant concepts: "imitation" "11 "contradiction", and "harmony" which are the axiom couples of "repetition", "encounter", and "adaptation" processes. Tarde categorizes life into three areas as physical, organic (living or vital), and social (Tarde, 2012, pp. 46, 55, 60) ${ }^{12}$, and he puts the monads as the main pseudo-element in each of these. He also traces the common features of the monads in each area, which mingle with one another constantly and regenerate as they interact. And the three areas consist of ever expanding systems, so openness becomes inevitable as the determining feature when Tarde places "continuity" under the ultimate "discontinuity". ${ }^{13}$

Similar to the relationship between the monads, contradiction and harmony are also determinant concepts in social relations. However, relations between living creatures and social relations between human beings

\footnotetext{
9 Will Durant observes the same strain in Schopenhauer, Nietzsche and Spinoza which he names as the "will to live" and the "will to power". He presumes that most of the philosophers agree on that. (Durant, 1960, p. 178)

10 On this issue see also Theo Lorenc's "Tarde's Pansocial Ontology", in his own English translation added as "afterword" (Tarde, 2012, p. 72-95).

11 "Le Lois de L'imitation" is one of his masterpieces, in which Tarde describes "imitation" as the basic concept which generates society. "Imitation" is essential to understand his ideas as a whole. However, his ideas of "imitation and repetition" aren't included in this paper, for this study is limited to examine Tarde's and Confucius' ideas of harmony (adaptation) and contrast.

12 Theo Lorenc also confirms the inter-areal similarities; "Tarde sees the supposed characteristics of the physical world - the forces of gravity or magnetism, or the solidity of matter itself - as humans' introspective self-perceptions..." (Tarde, 2012, p. 76).

${ }^{13}$ Tarde asks; "What do we place within [under] the ultimate discontinuity if not continuity? We place therein, the totality of other beings. At the basis of each thing are all real or possible things." It was also quoted in Lorenc's translation (Tarde, 2012, p. 90) in a similar context. Tarde wishes to bring infinity (continuity) at the end of the "infinity" as was rendered in Ulus Baker's Turkish translation (Tarde, 2000). He puts the monads in physical and vital areas and he places human beings in social relations and implies a sort of hierarchy, between the monads as the hierarchy between individuals, the idea which leads to the "network actor" concept of further studies. However, for Tarde the concept of social relation is much more inclusive than its initial meaning: He neither considers the material as a basis like atomists or materialists, nor pays attention to facts like Durkheim does; instead, imitation, contradiction, and harmony are principal determiners; in other words, he emphasizes the inter-elemental relations which have common features for each area. It is probably for this reason, he glorifies "social" and "sociology" as a basic concept, just an emerging science in his time, as he says: "...all sciences are seemed to be intended being branches of the sociology..." (Tarde, 2004a, p. 48).
} 
seem more developed and complicated: They are not detached but mutual; they diversify within themselves and outwards endlessly. But they are still identical with others due to the ever consisting balance on each phase. That different areas are identical with the idea of "two forces", one of which heading for the center and the other dispersing from it (Tarde, 2000, p. 70). Two forces, which are immanent to the monad, direct it towards symmetry within itself, and bring harmony and reconciliation with the others. Tarde says:

...in any field of truth whatsoever, consists in a passage from the great to the small, from the vague to the exact, and from the false or superficial to the true and deep-rooted; that is, it consists in first discovering or imagining a vast harmony of the whole, or a few grand but vague external harmonies, and in replacing these gradually by countless internal harmonies, forming an infinite number of fruitful, infinitesimal adaptations...(Tarde, 2000, p. 69)

Each system either consists of harmonious aggregates or exists in accordance with the conditions provided by higher aggregates of harmonies. Taken at a specific moment, which is the case within a closed system, it is possible to be examined. However, since the main element (human being in a social area or the monads in others) is open and changeable, there emerge consequences which cannot be predicted during the process that dissolves into encounters as contradictions in lower levels. The formation of a new convenient atmosphere is required as the encounter emerges, and the areas enable the discovery of new areas with outward expansion. In this sense, every encounter has to occur under the protection of certain higher adaptations. Thus, the "adaptation" emerges as an expression of "inclination towards adaptation", rather than a general static adaptation which repeats itself permanently.

The "two forces" are "desire" and "belief" in the human realm ${ }^{14}$ and one of which inclines towards the center while the other inclines outward (Tarde, 2000, p. 20) ${ }^{15}$. These forces form dynamic contradictions which integrate with each other. According to him, the contradictions in each area like internal forces are misunderstood by "average thinkers", as "differences in maximum level" (Tarde, 2000, p. 44). But indeed,

The contradiction is a very special kind of repetition, namely, of two similar things that are mutually destructive by virtue of their very similarity. In other words, opposites or contraries always constitute a couple or duality, they are not opposed to each other as beings or groups of beings, for these are always dissimilar and, in some respect, sui generis; nor yet as states of a single being or of different beings, but rather as tendencies or forces. (Tarde, 2000, p. 44)

By means of repetition, Tarde represents counterparts as tendencies, which are alike and destructive for each other. Therefore, the contradictions form couples and in the simplest way they are merely the varieties of inclinations. The elements which form the contradiction are couples which are equal to one another. These are forces which resemble each other in terms of their essence which are supported by the same source or sources, but they incline towards different directions. Tarde explains:

\footnotetext{
${ }^{14}$ Tarde points out that the desire-belief contradiction is expected to create harmony in human beings. This manifests itself in suspicion and/or indecision (Tarde, 2000, p. 71). Suspicion and indecision are removed with the provision of internal harmony again. Therefore, he thinks that the new idea, namely, "discovery" one of his main concepts, becomes possible. According to Tarde, the harmony in human being is very complex. He says, “... adjustment with one's self differs greatly, in phenomena of every sort, from the adjustment with others..." (Tarde, 2000, p. 71) The same approach may also be observed in the special use that he attributes to psychology in his writings. For him, psychology is a discipline that responds to the basic questions of people. Together with chemistry, psychology will satisfy all the needs of human kind; psychologists will enable order and harmony in society and chemists will provide food. As in his own words: “...our chemists have thus reassured us against the danger of dying of hunger, our psychologists have acquired still further claims on our gratitude in freeing us from the fear of death..." (Tarde, 1905 , p. 170).

${ }^{15}$ He thinks that taking two forces as constants, which will inevitably lead the thinker to the idea of essence; and this will result in either materialist or idealist thinking (Tarde, 2012, p. 20).
} 
If we regard certain forms or certain states, such as concave and convex, pleasure and pain, heat and cold, as opposites, it is by reason of the real or assumed contrariety of the forces which produce these states... (2000, pp. 44-45)

He points to the different inclinations of the same essence, one of which inclines towards inside and the other towards outside; the one is for pleasure and the other is for pain; the one is for hot and the other is for cold. Thus he claims that the real contradictions are comprised by the harmonious counter-inclinations which cannot exist without each other and are meaningful when together.

For Tarde, the contradictions are the harmonious couples which indeed complete each other. He assumes that the harmony is not an ultimate target, but a perpetual action, through which any other resultsare impossible. Therefore, the adaptation emerges as a de facto behavior. The two opponent forces protect the present cycle on the condition that they have an inner symmetry and an adaptive tendency to maintain balance, "Considered as a moving point, [a planet] reveals a harmony between its inclination to fall into the sun and its tendency to fly away at a tangent..." (Tarde, 2000, p. 70). Tarde also states it as follows: "However, if two forces which approach to the center and retreat from it, incline to consume themselves on the same straight line, this would cause a contrast" (Tarde, 2000,p. 70), but they don't. He points out that the present contradiction turns into a kind of harmony, and harmony and contradiction replace one another constantly as they function.

Although harmony and contradiction continually replace each other in the nature, Tarde attaches greater importance to harmony. This is because the things which insist on sustaining contradictive intensions cannot remain durable, consistent and even healthy as the ones intending to adapt. As there will be inevitable contradictions in all contexts, if every being insists on the contradiction with all its power, it will be forced to comply. Even if it is not a long lasting one, by adapting to the changing conditions at an optimum level, it will incline to resemble its previous form rather than bring the strain to a degree over its endurance, which would cause it to break into pieces or to be divided into different small unities. ${ }^{16}$

Adaptation functions in a more complex pattern in the social area. Tarde suggests that; "Any aggregation whatsoever is a collection of individuals jointly adapted, either some adapted to the remainder or all to a common function." (2000, p. 71). The adaptation of aggregate which tends towards a certain model via a theme and the individual's adaptation to the other individuals of the aggregate function simultaneously. Tarde draws a wide open axis and places immediate environment to one end and greatest possible extent to the other. In the most general status he manifests this in a two level pattern. He remarks: “...Adaptation of the first degree is that which the elements of the system in question have among themselves; adaptation of the second degree is that which unites these elements to the systems that surround them." (Tarde,2000, p. 71) ${ }^{17}$ Tarde further says: "Moreover, different aggregates which have relations with one another may be co-adapted; this constitutes an adaptate of a higher degree..." (2000, p. 71). Nevertheless, "the desire to live forever and to own" (Tarde, 2004a, p. 71) is common in every being and inevitably causes bunching, stratifying and regardless of its basis (religious, moral, caste, ethnic etc.) causes hierarchical structures to emerge around a center. For him, in spite of breaking up, centralization is the main intention (Tarde, 2004a, p. 87). In every step, contradictions are replaced by harmonies that fall under one another and integrate into smaller units. Thus, we observe that the needs are met more accurately in each level (Tarde, 2004b, p. 99).

\footnotetext{
${ }^{16}$ For adaptation as a general law, Tarde says that "the brightest stars are not always the best ones," and remarks that the cases point not to "maximum" but "optimum" in every situation.

${ }^{17}$ For Tarde, open systems are related to ever spreading surroundings. Thus, when the relation and causation are in question, Tarde indicates, "There is possibly everything behind everything" and thus he associates everything with the aggregate.
} 
Tarde thinks that society depends upon "exchange of reflections" (1905, p. 16) and in "Monadology and Sociology" he defines society in the simplest way: "From our perspective, it is the fact that everybody owns each other singly and mutually in extremely different ways" (Tarde, 2004b, 78). Interpersonal relation is a kind of mutual cognition and adoption activity, and society is an aggregate made of individuals, institutions, and other elements by which various kinds of adoption formed. In any case the individual interacts, conceives, and owns the others, at the same time he is conceived by them and ultimately by the whole society. This mutual possession occurs "in a thousand ways." For instance, a child who owns his mother, in fact owns a mother with a child, and the child owns the mother who has a husband who is the father of her child at the same time; gradually she is also owned by the friends of her child with the reputation of "aunt $\mathrm{x}$ ". Thus the mother gains unceasing and ever growing attributes in every situation. This way she is connected to the society "in a thousand ways" and she owns the whole society with her cultural background. This network spreads in a similar way for every individual in society.

For Tarde, the individuals are the actors of their environment where they live in a continual interaction with their surroundings. As one adapts to his environment, he expects adaptation from it. This opens a door for a possible and ideal unity; this environment may be a family, a certain social class, or a nation. Tarde, however, spares religious organizations for being profound but his depiction of this ideal society is secular in structural terms,

...a world which is enigmatic and undecipherable from the outside, where mysterious passwords known only to the faithful are exchanged, - a conservative world in which all must conform scrupulously and indefinitely, with remarkable selflessness, to the traditional rites, - a world which is highly hierarchical, yet whose inequalities seem never to provoke rebellion - a world at once highly active and highly regulated, highly persistent and highly flexible, capable of adapting readily to changes of circumstance and yet persevering in its age-old beliefs....(Tarde, 2012,p. 63)

Tarde's underground world in which mysterious orders are accepted as truths, ceremonies, or rituals is obeyed meticulously with self-devotion. This world is defined by hierarchies but inequality does not cause rebellions. What is more, the people are skilled in adapting to new conditions, and determined in their centenary thoughts and purposes.

With a closer look, the consistent relation between two individuals seems to be an interchange which meets and satisfies the needs of both parties:

Shall we not say, then, that the fundamental social adaptation is, in the last analysis, that of two men, one of whom answers, by word or deed, the question of the other, whether silent, spoken, or tacit? I call it a 'question' for the satisfaction of a need, like the solution of a problem, is the answer to a question. Shall we not say, then, that this fundamental harmony consists in the relation between two men, one of whom teaches, while the other learns-one of whom commands...that it consists in the relation between two who work together to produce the same result? (Tarde, 2000, p. 77)

As we follow Tarde, we see that the harmony functions in every area and gets multiplied; it diversifies and solidifies with the equilibrium which is re-balanced once again with each step. The individuals who relate and mutually adapt to one another; have to move from a certain aspect that they can conceive each other and approach each others from a right angle. As an example in the physical area, Tarde says; "only when planets move in a right angle towards each other, adaptation occurs" (Tarde, 2000, p. 70). The same is true for social relation; the right angle is located somewhere in internal adaptation and continually changing external conditions. This is an ideal stage of a "continual change in unstable equilibrium". 


\section{Harmony (和) in Chinese and Related Concepts}

The "unstable equilibrium" or "the right angle" which is particular to every being is also present in traditional Chinese thought as the natural law (li). The concept of $l i$ as a natural law manifests itself in taiji as the symbol of coherent unity depicted in the simplest way. From the smallest to the greatest, the law of $l i$ or taiji directs existence and the change of "myriad things" in nature. ${ }^{18}$ It also depends upon the two opponent forces which are presumed to be present in nature, and the $l i$ has a position above them.

It is remarkable to see that Tarde understands harmony and contradiction quite similar to the basic conception of Chinese traditional thought. In the traditional Chinese understanding, yin-yang is a general name representing the contradictions and dichotomies in the nature. It is commonly accepted that the yin-yang is present in every being as two opponent forces. ${ }^{19}$ They can be observed in the healthy and steady togetherness of entities - as in human beings - and also obvious in natural dichotomies such as night and day, summer and winter, hot and cold.

As depicted by taiji symbol (yin-yang), basic harmony of counterparts is one of the most apparent conceptualizations in Confucian cosmology. As in dichotomies and aggregates, harmony ( $h e$ 和) is considered as a principle that exists both in nature and people. Harmony is a principle upon which people are expected to depend continually. ${ }^{20}$ In the Confucian canon called "Doctrine of the Mean" we may see a depiction similar to Tarde's:

When the feelings of pleasure, anger, sorrow and joy do not exist it is called Equilibrium (中). When those feelings comes out and join it is called Harmony (和). This Equilibrium is the great root of the world and Harmony is the universal path. When equilibrium and harmony is achieved, heaven and earth find their [true] place and all things get nourished and

\footnotetext{
${ }^{18}$ Identification of these two concepts to each other is prevalent in Cheng Brothers and in ZHU Xi, the founders of "Li Xue (or Song Xue)" tradition which lasted until modern times in China.

19 One of the best narration for yin-yang is found in CAO Xue-qin's "HongLou Meng (Dream of Red Chambers)"; “...Everything, from old till now, from the very creation itself, embodies a certain proportion of the Yin and Yang principles. Everything embodies a certain proportion of the principles Yin and Yang. Besides, the two words Yin and Yang are really one word; for when the Yang principle is exhausted, it becomes the Yin; and when the Yin is exhausted, it becomes Yang.......at the exhaustion of the Yin, Yang comes into existence; and that, at the exhaustion of the Yang, a Yin arises... ... [They] are no more than spirits, but anything affected by their influence at once assumes form. The heavens, for instance, are Yang, and the earth is Yin; water is Yin and fire is Yang; the sun is Yang and the moon Yin... ... all those mosquitoes, flies and worms, flowers, herbs, bricks and tiles have in like manner... ...even the leaves of that tree are distinguished by Yin and Yang. The side, which looks up and faces the sun, is called Yang; while that in the shade and looking downwards, is called Yin...” (Cao; Gao,2003,p. 426). We may further the idea by speculating; the body is Yang and branches and leaves are Yin in which mere leaves are Yang, while the branches are Yin; bark of the branches are Yang and inner side is Yin, root is Yin and the tree itself is Yang etc.

${ }^{20}$ This approach emphasizes that a human being is a part of the surrounding and nature, finds the best manifestation in the idea of sky-human interaction of Dong Zhong-shu. Sky-human interaction is established on the presupposition that right and convenient behavior is related to the "realm of good" and the inconvenient ones are related to the "realm of evil". It is considered that mainly the activities of the rulers as the deeds of common man have reflections on heavens. Therefore, it is tried to direct human behavior by processing the good ideals continually when the prominent samples of the ancient history are remembered and observed. Through time the recurrent processing of these examples formed thick layers of norms; human behavior is restricted to liabilities and responsibilities, positions, tasks and roles were determined with general principles. This is called as tian-ren ganying 天人感 應 Sky Human Interaction or Sky Human Unity 天人合一; See Han History 2495. Dong Zhong-shu is one of the chief advisors of Han Wu Di. From then on Sky Human Interaction, started to define the position of people, and turned into a tool in politics to manage society. However, the interest of the power was still directed to removing strains to achieve harmony in Chinese political philosophy.
} 
flourish. (Ames, 2001, p. 19) ${ }^{21}$

Tarde's trans-areal feature of harmony is also prevalent in Confucian terms. While the "equilibrium" is the root (本), "harmony" is the path (道) to be pursued. The response to the question about "what is consistent?" or "'how to be consistent?" calls for another concept and reconciliation which is possible to be observed in the relation of harmony with $l i$ (law里). However, $l i$ also has the meaning of "reason" in contemporary Chinese.

The true meaning of $l i$ is "to process jade"; this activity is processing the crude form stone in consistence with the veins, lines and shapes in it and revealing the essential form in the object according to its length, angular, or round lines, hardness, and weight of the stone. Therefore "li as a natural "law" is not absolute or unchangeable. It is neither divine nor related to a law inspired from an absolute or transcendent essence. Rather, it corresponds to a kind of "revelation" similar to Heidegger's definition of "technique". However, $l i$, unlike technique, is not a design divided into pieces and formed to be examined in reasonable variety, and is not dealt with as a reality independent of time category which ultimately corresponds to mechanic. On the contrary, the foundation and reference point of $l i$ is nature and natural cycle.In the strict sense, it is related to the immediate environment and duration. It is a kind of spontaneous revelation trying to keep the same distance to both time and space.

$\mathrm{Li}$ means giving shape, processing and arranging things coordinately with their nature; it also corresponds to "order" in the oldest dictionaries. ${ }^{22}$ From familial affairs to all kinds of phenomena in nature, it is an image which helps to explain why the life is the way it is, but not some other way (ZZXS, 1980, p. 55). From the smallest fragment to the greatest universe known, it is inherent to everything and at the same time has an inclusive position above them all. Thus, $l i$ is presumed to be the correspondent of the equilibrium and consistent cycle in nature. ${ }^{23}$

In terms of ideal harmony and equilibrium the law of $l i$ is called taiji (太极). Taiji finds its accurate meaning in yin-yang symbol. The idea of contradiction represented with yin-yang is not an antagonistic contrast in this sense, but rather the relation of the elements which depend on and stimulate each other. ${ }^{24}$ The most remarkable character of this idealized symbol which is quite similar to the contradiction concept of Tarde, is that they are both intensions rather than being constant opposites. As a representation of $l i$, black and white areas in taiji symbol are set in counter positions, they intertwine and look as if they are embracing and chasing each other. In the midst of both elements there is a sizable dot from each other. These opponent parts which

\footnotetext{
${ }^{21}$ James Legge in his translations of this fragment slightly modified it to the "human's realm”. Whereas the original text is; “...喜 怒哀樂之未發, 謂之中 ; 發而皆中節, 謂之和 ; 中也者, 天下之大本也 ; 和也者, 天下之達道也。致中和, 天地位焉, 萬物育焉.” (Zhongyong: 18)

${ }^{22}$ Shuwen Jiezi 说文解字(Explaining and Analyzing Characters) is one of the oldest and the most comprehensive dictionaries. It was compiled by Xu Shen 许慎 in Eastern Han Dynasty compiled between years 100-121 A.D. Comprised of 9353 characters in 14 sections with explanations. Its copies appeared in later periods.

${ }^{23} \mathrm{Li}$ is to give a shape and organize things in accordance with their nature. When everything is organized in this way an ideal togetherness in which the most consistent cycle in the true positions for every part occurs. Mengzi points this out as ideal order; "What is the meaning of the union of (everybody's) heart?" asks Mengzi and then responds; "this is called law and truth" (Mengzi 7). According to another eminent thinker of Chinese thought, ZHU Xi; "this law is not hollow, it is a real one, the real path is in this flow as winter follow summer or day follows night" (Zhu Yu-lei). The harmonious cycle in nature is the law itself and the law precedes everything; this sky and earth could exist because there was $l i$ " says ZHU Xi, "if it did not exist, neither human being nor myriad things could exist" (Yang, 1982, 123).

${ }^{24}$ Sharot in his study compares the world religions sociologically and remarks as; "Social order in China is perceived as a reflection of harmonious and balanced cosmic order" (Sharot, 2001, p. 16) for the historical development of this idea; see YAO 2000, pp. 169-178. Bodde discusses harmony and conflict in Chinese philosophy in Wright (Ed.) 1953, pp. 19-81.
} 
emphasize that neither of the two can exist without the other, and this also points to the fact that even if one of them expands to a point that can possess the other, it can only keep embracing its inner counter and cannot remove it. Otherwise, if one of the elements becomes strong enough to remove the other by spreading, it will transform into something else. Then it will have to take its part to form a new element of another higher dichotomy, which is inevitable in a new equilibrium. Moreover, this symbolic contradiction we are discussing on an individual basis still contains countless other smaller contradictions and is invariably affiliated with higher equilibriums. This shows that in contradictions the best way to exist is to adapt to the most consistent cycle with the natural procession of the context.

Taiji equilibrium and law of $l i$ has been considered to be identical. In the highest manifestation of $l i$, there is taiji, balance of yin-yang powers (Chen, 1988, p. 221). Nothing, which is subject to law, is independent from the balance within and it's also connected to the yin-yang dichotomy. What is more, any contradiction represented with yin-yang dichotomy has a kind of mutual interdependent relation which intertwines with the law in every context.

Like everything in nature the law also depends upon yin-yang forces. If we try to approach from the point of sky-earth (tian-di) dichotomy; ${ }^{25}$ we see that earth and sky are also subject to $l i$ in terms of existence and require the vital $q i$ force $^{26}$ to operate. The earth and sky has their own law and vital essence and when we examine $q i$ of the sky closely, for instance, we may see yin-yang forces reappear.The six forces of the sky are recorded in Zuozhuan as; wind, rain, darkness, light, and yin-yang (Zuozhuan: p. 48). ${ }^{27}$ Though yin-yang is the highest category, it also occurs among others in sub definitions and aggregates. In this manner, yin-yangprovides open and dynamic contexts which are comprised of determinative elements in lower and upper categories and the elements may reoccur. These contexts expand from center to environment gradually and are reestablished with the supervision of activities in higher contexts; they activate in direct proportion with their vicinity to the center, and as they become distant, their power weakens, increases in number, ramifies and diversifies.

\footnotetext{
25 The most prominent example of contradiction in traditional Chinese thought is sky-earth dichotomy. "Supernatural" corresponds to the sky with the form that we understand, "secular" corresponds to the earth, but the fact that the sky and the earth are always intertwined proportionately. Traditional Chinese thought which makes a distinction between the sky and the earth, namely supernatural and secular, defines the secular one in an open way, it seems to avoid connecting supernatural to stable definitions - as it may be that its nature requires this. The sky is displayed as the main source from which the rulers take power, and becomes superior to the Earth; the "will of the Sky-heaven" is certain and the Earth has a passive position against it. The sky associated with the active force (yang) is considered a main area of the "obscure universe", and its priority can be explained with the fact that the changes in nature occur slowly but with a spontaneity which cannot be hindered and the signs of this change are primarily observed in the Sky or air surrounding us. However, the Sky which has a significant place in traditional literature it is not placed in an absolute, transcendent position above cosmos, mostly mentioned together with its opponent (i.e. correspondent). The Earth was not converted to a "pan creator" unlike the understanding in Abrahamic religions. Thus, Confucius refers to spontaneous harmony in nature, and asks: "How does the Sky speak? It circles along four seasons, beings are born, how does the Sky speak?" (Lunyü,1994, p. 17)

${ }^{26} Q i$ represents a rising cloud ideographically, and it means cloud or vapor. Moreover, $q i$ has various meanings such as scent, breath, air, atmosphere, character, temperament, quality and luck, so it is seen that its competence to move comes prior to its role as a building stone which forms things. He says in the Book of Rituals; "while qi of the Sky descends and goes down, qi of the Earth ascends." (Liji: 86). At the same time, Qi is the vital essence. In Rituals we read; "the sky has time, the earth has qi, the beauty in the material and good craftsmanship. Although the good material and the craftsmanship are competent, when there is no beauty, [then it means] the time and qi is not possessed yet" (Liji: 84). One of the most efficient followers of Confucius, Mengzi names qi as the essence "which fills objects." (Mengzi: 264) So the qi can be understood as a moving, intertwining, mixing and reuniting, half living essence and an aggregating force. In this respect we can consider $q i$ as an essence which is similar to Tarde's Monads.

${ }^{27}$ Zuo Zhuan is one of the most respected annotative copies of "Spring and Autumn" which is considered to be compiled by Confucius is among the most revered "13 Classics".
} 
The process of internal balance and conformance to the ever changing external conditions recalls a "harmonious undulation within the natural cycle". This finds a most prominent example in Laozi: "the greatest mastery is to be like water" says Laozi, "water lives in contemptible places without struggling with others and so it is the closest one to dao..." (LZS, 1992, p. 38). Water's fluidity and ability to overcome obstacles, its softness and natural tendency to adapt in motion, then poses a model. ${ }^{28}$ In this respect, the symmetry of motion in time is also pursued just as the balance in space is observed. Fluidity of motion should be considered, but it can only be measured gradually and in quantity.To realize its suddenness or severity, the basic criterion shall be coherence, spontaneity, or naturalness. Therefore, the (inner) balanced and (outer) adaptive motion not only requires some kind of a mutual concordance between the elements in the context, but also requires the harmony within the whole process. With his "millennial knife" envision Zhuangzi ${ }^{29}$ gives a striking example to the fluent and natural movement. The butcher Zhuangzi depicts is so dexterous and performs his work in such a fluent way that his knife does not become blunt even though he works with it for a lifetime nor he needs to sharpen it even once; but the knife remains as sharp as it was in its first day (Laozi Zhuangzi Sayings, 1992). Laozi depicts $l i$ on an ideal plane.

Time is an aggregate which shows continuity and also a reminder of the necessity of harmony and fluence in human behavior. Thus, it is expected to behave in line with the adaptive approach in all activities for good and all. People should avoid being insistent on their actions and be adaptive in their relations with each others. Just like there is a proper way to carve a jade stone, there are proper ways for human deeds in all conditions. The individuals are never free from their intimate environment, and against their personal desires.They are strictly bounded to the $l i$ which is valid in all circumstances. Thus, people are re-connected to the environment which they belong to.

Tarde suggests that there is a contradiction between "desire" and "belief". He presumes a tension between the two and he remarks that desire is supervised by belief. On the other hand, in ancient China, desire is controlled and suppressed by the law of $l i{ }^{30}$ As the law restricts insistent desires which are to be curbed, belief occupies a significant place within law as a motive or an inclination. For the belief ${ }^{31}$ perpetuates a kind of reliance, it ensures the connection point of fluent harmony (law) of the deeds, with the driving force (i.e. desire: yu,欲). Confucius, reflecting on "belief" says: "Can there be any person without belief? This is like a cart which has no connection shackle with the horses". ${ }^{32}$ (Lunyü,1994, p. 22). A harmonious aggregation can be achieved by connecting desire to law via belief. Adaptation is not an isolated process experienced alone, free from natural cycle. Therefore, Confucius reminds $l i$ by criticizing those who "fall behind" as a result of their

\footnotetext{
${ }^{28}$ Although convenience to path, namely, "virtue", is discussed in Confucian texts as different from Laozi, but both traditions mention the same "path" and the change in shi-xu 实虚 resonance paves the way for verifications in quantity. Both traditions basically maintain the same ideal. The adaptive behavior idealized in each tradition, if we remember the famous anecdote about Confucius visiting Laozi.

${ }^{29}$ Zhuangzi live between A.D. 369-286, is one of the most efficient thinkers of Taoist tradition. Today his work “Zhuangzi” 庄 子 (known as Nanhua Classic as well) is comprised of 33 sections.

30 The "belief" of Gabriel Tarde is not a religious reflection of the heap formed by theology indeed, it is a kind of act with the secular meaning of the concept. He claims that the thinkers did not regard the 'belief' and did not think of 'breaking belief into pieces and look into it.'

${ }^{31}$ The symbol of "belief" in Chinese is comprised of the combination of the symbols of "human" and "word." It points to reliance, sincerity and especially the activity of believing itself. It means sincerity, honesty and truth as well.

32 Confucius associates belief with the moving shackles that the axles are connected to both sides of cart: in this comparison horses correspond to desires and the cart meets the law, the moving shackles that correspond to the belief are the part which belong to the cart (the law), if there is no shackles, there is no cart as well. He shows that a person without belief is impossible.
} 
inabilities, and those who spoil it with extra force (Zhongyong 4:1). Thus, the ultimate goal is to maintain a sort of awareness which will lead us to adapt to the ideal harmony that flows in nature. To a certain extent, then, it seems to be an ethical interpretation of Tarde's concepts of adaptation and harmony.

In social life, while adhering to the rules, people still need freedom to adapt themselves to new conditions. "Can you disregard rules?" asks Confucius. This is due to the fact that rules have been proven to be effective in ensuring the order of hierarchy and civil order in all aspects of social life. ${ }^{33}$ Nevertheless, no matter how strong and well-established they might be, rules should be open to changes. Confucius concludes by saying; "rules' value lie in their reform" (Lunyü: 9:23).

Reforming the rules when necessary is a precondition of harmonic behavior. While the order of the universe is seen as the constant (way) rules of "profane" life, these rules don't need to be exact. Awareness, which makes reform and effective change possible, is gained through adaptation. To adapt to a new situation through constant change, one needs to be "aware" and flexible. Thus, Confucius says that he refuses four things: "speculation, definite judgment, selfishness, and inflexibility"(Lunyü: 9:4). Moreover, one of Confucius' greatest fears is a state in which the good and the appropriate cannot be changed (Lunyü: 7-3). This emphasis on change and openness separates Chinese thought from other traditions of thought. Not presenting an "absolute law" or a "law maker" as its focal point, then, Chinese thought provides due conditions for the secular concepts, such as "human relations" and "harmonic consensus".

In Confucianism the key point of social structure is "human relations". The most distinctive concept of Confucian society is "ren" which can be interpreted as love for all human beings. The Chinese symbol for "ren" is formed by the combination of "human" with number "two", and refers to the relation between two people, denoting humanity and the potential to live as humans. Ren indicates a love which primarily forms in family and extends gradually from close friends to the others. This love forms a circle which widens as it moves away from the centre and with each step its relation to the centre is reviewed and adapted. Here, Confucius' main focus is on immediate surroundings. He says, "Human relations (i.e. ren,仁) in immediate surroundings is beautiful" (Lunyü: 4:1) and indicates that the most harmonic relation can be achieved within this intimate circle. One should raise himself according to the "way"; and review the "way" according to human relations (ren). (Zhongyong 20:4) If we draw an axis for ideal relation, then, one of its ends is universal love, and the other is constantly reviewed love, not hate or absence of love. In changing conditions, harmony remains between the two. Under the umbrella of love, as a means for the ideal human relation, relations formed with sincerity and faith feed the conditions of the ideal togetherness and contingency of momentum, where the whole can create an ideal harmony. In this respect, the key to the ideal human relations (仁) is an ethical principle which was enigmatically drawn by Tarde in his, "a child who owns a mother that has a child" postulate.

A closer look reveals two more concepts which direct the relations on every stage. The first one is "humility" (knowing one's place), which organizes the relations of superiors and inferiors, and the second one

\footnotetext{
33 These models are the exemplary lives of wise and able rulers and their legacy of rituals. For Confucius, the gentlest manifestations of human life are rituals. Ideally, ritualized behavior desired to penetrate into all aspects of life, provide means to organize the complex hierarchy of order. Rituals are the field where uncertainties which may cause trouble are foreseen and prevented. It purifies people of doubt, and prevents indecisiveness. On a closer inspection we can discern that there are two basic criteria for rituals: "sincerity" and "harmony". "Be sincere at the rituals, if I'm not sincere I don't conduct rituals" says Confucius (Lunyü: 3:12). Sincerity means to turn to someone or something with earnestness, to set one's heart on the work at hand, and thus, it means more than a simple honesty. Just as in performing music or calligraphy, one needs to lose himself in the rhythm or the theme, and be one with the flow of the work. Harmony is an active effort to adapt rather than a succumbing one. In his Analects, Confucius says: "Harmony is the thing gives value to the rites" (Lunyü: 1-12).
} 
is "benevolence". Humility directs the behaviour of inferiors while benevolence directs the behaviour of seniors and withholds them from behaving arbitrarily towards humble inferiors. These two concepts are shu (恕) and zhong (忠), respectively. Shu is the ability to put oneself in another's shoes and is the only permanent principle of Confucius. When his student Zigong asks if there's anything to be pursued for whole life, he answers: "That's shu", the ability to put oneself in another's shoes (Lunyü: 5:24). As is known, this concept is regarded as the "golden rule". ${ }^{34}$ Today this definition is associated with humanity, but in old times it used to organize social status and positions.

In an open construct, where everyone acts in accordance with his position, forms his relations within the frame of general principles and reviews them with each new situation. Thus harmony and adaptation inevitably emerges as the focal point. In his Utopia, Tarde portrays this unified harmonious society:

...An indescribable courtesy, skilled to charm without falsehood, to please without obsequiousness, the most free from fawning one has ever seen, is united to a politeness which has at heart the feeling, not of a social hierarchy to be respected, but of a social harmony to be maintained.... (Tarde, 1905, pp. 141-142)

The "loyalty" that Tarde speaks of can be understood as the loyalty and faith felt towards the underground society's own great ideal, and towards the idea of its unification. Social harmony is an inevitable harmony to emerge in a closed society, out of which it is impossible for people to survive. People, having nowhere else to go but for the depths of the Earth, transform into more harmonious and balanced social humans, and as the planet cools down they become even more civilised on each level (Tarde,1905, p. 142). Contrary to the ever changing "open" environment of the surface, ideal relations are possible to be actualized only here, in this "closed" environment. Thus, harmony and (human) relations become the sole principles of the virtuous man as he gets civilized. ${ }^{35}$

In traditional Chinese thought, avoiding contradiction is advised so as to protect the autonomy and individuality of different groups, societies and the individuals who form the social union: "Virtuous man stands firm but does not contradict, brings the people together but does not discriminate." (Lunyü, 15:21) "...being harmonious but not resembling to the others..." (Lunyü: 3-23). On the other hand, in order to protect and enhance individuality and diversity, Tarde says: "Society.......consists in the exchange of reflections. Mutually to ape one another, and by dint of accumulated apings diversely combined to create an originality is the important thing." (1905, pp. 116-117) This means imitating each other and regains individuality in return. In a similar way, he thinks that the "society is based on a variation of reflections". For the government he suggests a democratic, elective merit system in which the voters identify themselves with the people they vote for (Tarde, 1905, p. 132). Yet, the distinction between the governing and the governed is abiding, and regulations are made by the higher classes, not by the lower ones. However, in Chinese thought regulations tend to start from the individual on a moral basis. Ideal harmony represented by yin-yang is dynamic, open, and variable. It does not signify an ultimate certain end or an absolute state, nor does it propose a fixed status. When something emerges, its law (li) emerges with it. Thus, on the point of existence the new thing does not remain limited with a

\footnotetext{
${ }^{34}$ The measure of relations between equals or friends is sincerity and faith. Confucius says, "I check myself three times a day" and each time he questions whether he is sincere towards his friends (Lunyü: 1-4).

${ }^{35}$ It seems that, by moving people underground, Tarde can realize his harmonious society which he believes to be achieved within a closed system. However it wouldn't be right to think that Tarde's society is completely closed off, and the hysteria that spreads throughout the society in every May, and lovers' suicide by throwing themselves to the surface implies that. In this ideal life, "openness" for Tarde means destroying oneself by not succumbing.
} 
"possibility". By the context, which varies in each step, it becomes inevitable with the help of momentum,so that innovation can be presented with the cumulative development of harmonious activities over a long period of time.

Tarde's harmony, like its Chinese counterpart, is dynamic and natural. It is a dynamic whole of adaptation processes which is present as a general law in universe and in every aspect of life. Tarde, quoting natural phenomena, exemplifies adaptation in "Social Laws" as:

...consider a river bed, here we find a mountain range or a roll of hills adapted to the flow of the river. We find that the light of the sun adapted to the rise of the ocean's vapor to the clouds. Moreover the winds have adapted in carrying these clouds to the mountain peaks. Here they transform into the rain which feeds springs, creeks and rivers. (Tarde, 2000, p. 70)

Just like Tarde's "mountain adapting to the river", the Chinese jade stone highlights artisan's participation into the adaptation process which signifies a moral direction. The social harmony and adaptation we see in Tarde's thoughts are among the subjects Chinese thinkers dwell upon most. However, in traditional Chinese thinking, natural harmony and consensus in social interactions transforms into an ethical doctrine. The idea of carving the stone according to the veins in it, in a manner pleasing to both the stone and the artisan himself in which neither is strained, means that natural harmony is possible also for humans. As the artisan, the individual bears this in mind in his every deed, and thus people are credited with initiative.

In traditional Chinese thought, the idea of time's continuity and integrity necessitates the consecutiveness and flow of life in general, and the harmony of deeds in particular. "The premonition of future by knowing the past" (Daxue: 1) brings the individual closer to the ideal harmony at any given moment. For Tarde, however, time has a divisible and arrangeable character. The idea of consecutive deeds, flow of life and harmony is not prevalent in his ideas. In this respect, he is a positivist. For him, like many other things, time is an object which needs to be planned out and organized. Regarding the adaptation to the environment, Tarde emphasizes human selfishness, and this opinion of Tarde is manifest on his postulate: "the child is born a despot". Nevertheless, in traditional Chinese thought, then, except for the Legalist School and Xunzi, the mainstream view is just the opposite which accepts that "human beings are born good". In this regard, in Chinese thought, the control and subduing of individuals' desires and ambitions to ensure the harmony of social life is provided by the immediate environment, and formed around the concept of "law" ( $l i)$. Tarde, however, had to eliminate desires in its entirety to ensure social harmony in his utopia. For Tarde, harmony is achieved by disregarding "unconformity"; Confucianism, on the other hand, accepts that "unconformity" is always present and tries to find ways to provide conditions to change it.

Adaptation and harmony is conceptualized in Chinese thought similar to the way Tarde understands it. In "centre-vicinity dichotomy" placed on "two degrees", "surrounding systems". The limits of human behavior are also defined with this harmonious attitude, and it is considered as a criterion for civilized behavior. Conformity to the way harmoniously is the virtue. The virtue is the reflection of the law on human beings, which has limited it as a principle for everyone. ${ }^{37}$ Tarde accepts that

\footnotetext{
36 Two degrees: “...the harmony at the first degree is elements harmony within them and the second level of harmony is with the surrounding systems" (Tarde, 2000, p. 71).

${ }^{37}$ What is meant by virtue is not a complete code of right behavior readily obtained from a supernatural source. It is a collection of values gained by observing nature, and passed down through tradition which is naturally harmonious with the given structure, and it is acceptable. Virtue or suitability to the path in Confucianism, may be approached from a different angle, compared to the naturalist thinker Laozi, both traditions speak of the same path 道, same ideal order.
} 
harmony is in a close relation with time, the flow and spontaneity in nature, but maybe because of its complexity, he makes an exception for social life. The reciprocal harmony of human behavior is determined by some "unchanging rules". Adaptation is regarded only as a tool, a key to pass from one level to the other. In this respect, Tarde's harmony does not suggest strict ethical principles to be closely followed by the individuals. In uncertain intermediary conditions between "two levels" where adaptation is experienced, he leaves the individual in a state of indecision.

In "Fragments from the History of Future", Tarde's thoughts on the Chinese, whom he bestows upon the honour of adaptability to the underground life aside from his ideal society is not so positive at all. He emphasizes that their public consciousness is not fully established. Despite their practical competence for adaptability and harmony, he regards their traditional understanding lacking in long range social programs.

Instead of confining themselves as we to turning to account the deposits of animal carcasses, they had shamelessly given themselves up to ancestral cannibalism. They were thus enabled, seeing the thousands of millions of Chinese destroyed and buried beneath the snow, to give full vent to their prolific instincts. Alas! Who knows if our own descendants will not one day be reduced to this extremity? In what promiscuity, in what a slew of greed, falsehood and robbery were these unfortunates living! The words of our language refuse to depict their filth and coarseness. With infinite pains they raised underground diminutive vegetables in diminutive beds of soil they had brought thither together with diminutive pigs and dogs. (Tarde, 1905, p.159-160)

Although conflicting with his claim for universality, Tarde's underrating prejudices are most probably based on common "orientalist" views and show his devotion to the Western civilization;

These ancient servants of mankind appeared very disgusting to our new Christopher Columbus. These degraded beings (I speak of the masters and not of the animals, for the latter belong to a breed that has been much improved by those who raised them) had lost ail recollection of the Middle Empire and even of the surface of the earth. They heartily laughed when some of our savants sent on a mission to them spoke to them of the firmament, the Sun, the moon and the stars...They listened, however, to the end of these accounts, and then in an ironical tone they asked our envoys: "Have you seen ail that?" (Tarde, 1905, pp. 158-59)

\section{Conclusion}

With the progress of civilization, possessions become increasingly possessive, until the equality of rights, dominion of the people, and exchange of services in an equal and right manner. old slavery which has become mutual and universal transforms everyone into each other's master and slave. Today, these words seem highly optimistic. Tarde claims that:"the increasingly progressiveness of modern life, will make new industrial relations inevitably diverse with each mission" (Tarde, 2004a, p. 79). With further development of industrial branches, he argues that people's relations with their jobs and with one another will also diversify. Individuals will progress as their missions and skills vary, and will have various entities and expansions. ${ }^{38}$ Yet, it is doubtful that the diversification of specialties with their hoped for forms of relations, can produce individuals with diverse points of view and different approaches. Just the opposite, this diversification results in the emergence of individuals who having received a monotype education and by means of a shallow composition of their skeleton key-like perspectives capable of changing form only superficially. Thus, individuals become copies of one another to serve the needs of the market economy. The most distressing aspect of this general

\footnotetext{
${ }^{38}$ However, it seems that Tarde tends to an optimistic attitude that the difficult thing will occur. It can be clearly seen that progress usually does not exceed a certain level of acceptance. The awareness Tarde envisioned is there to be seen in today's modern individuals.
} 
tendency is that it almost never touches upon basic human values such as the sanctity of life and spirituality which is common in all moralist traditions.

As nations return to their cultural roots and the need for a universal ethics arises, it is thought-provoking that the Western civilization's "welfare society" cannot provide even its own people with the imagined happiness. The ideas which have been on the rise since the Industrial Revolution, such as science's responsibility to elevate humanity, and the belief that the doctrine of science which is considered to be belonged to the West will bring the salvation, is very much doubted after the fall of the socialist regimes and especially since the invasion of Iraq. On the other hand, individuals' need to organize their inner world is not a notion that belongs to the modern world. Every tradition and primarily religions have laid doctrines to organize human life. Chinese traditional thought, though not prevalent out of the East Asian Cultural sphere, is one of these. In this respect, modernity's lack of an esoteric model and insufficient appeal to the spiritual attempts might not be the conclusion, but the start of a new debate.

In many Asian countries, in parallel with the relocation of economic and financial centers, improvement of life standards though only for a specific portion of the population is partly responsible for the revival of the spiritual hunger in people. In this process, China is also returning to her roots. As China redefines herself culturally, will the optimistically outlined values as harmony prove themselves functional? Which values will adapt to the coming ages? Yet, another important question: If the "confrontation" Tarde fictionalized in his Utopia happens on the surface, how will both sides claim their "harmony" or "adaptation" to each other?

\section{References}

Ames, R. T. (2001).Focusing the familiar: A translation and philosophical interpretation of the Zhongyong. Honolulu: University of Hawaii Press.

Bodde, D. (1953). Harmony and conflict in Chinese philosophy. In A. F. Wright (Ed.), Studies in Chinese thought. Chicago: University of Chicago Press.

Cao, Xue-qin, \& Gao, E. (2003). Hong Lou Meng红楼梦 (The Dream of Red Mansions). Beijing: Renmin Wenxue Chubanshe.

Chen, Q. (1999).Zhongguo Zhexue Shi中国哲学史 (History of Chinese Philosophy). Beijing: Beijing Yüyan Wenhua Daxue Chubanshe.

Collingwood, R.G. (1999). Doğa Tasarımı, (The Idea of Nature). (Kurtuluş Dinçer Trans.). Ankara: İmge Kitabevi.

Daxue大学. (1996). Sishu Yizhu四书译著, Jilin: Jilin Wenshi Chubanshe.

Durant, W. (1960). The Story of Philosophy. New York: Pocket Library.

Huang, S. (1999). Essentials of Neo-Confucianism: Eight major philosophers of the Song Ming periods. Westport: Greenwood Publishing Group, Incorporated.

Ivanhoe, P. J. (1990). Ethics in the Confucian tradition: The thought of Mencius and Wang Yang-ming. Atlanta: Scholars Press. James, L. (2000). Chinese Classics (Vol. III). Taipei: SMC Publishing Inc.

Liji礼记 (Book of Ceremonies). (1982). Beijing: Shangwu Chubanshe.

Lunyüi论语(The analects of Confucius). (1994). Beijing: Beijing Foreign Languages Press.

Lunyü论语(The analects of Confucius). (1996). Sishu Yizhu 四书译著. Jilin: Jilin Wenshi Chubanshe.

LZS. (1992). Laozi Zhuangzi Sayings. Beijing: Qilu Shushe.

Mengzi孟子(Mencius). (1996). Sishu Yizhu 四书译著. Jilin: Jilin Wenshi Chubanshe.

Needham, J. (2000). Zaman ve Doğulu Insan:Beşeri Hukuk ve Tabiyat Kanunları, (Time and Eastern Man: Moulds of Experience a Pattern of Natural Philosophy). (Nejdet Özberk Trans.). Istanbul: İz Yayınc1lı.

Nivison, D. (1953).The problem of knowledge and action since Wang Yang-ming studies in Chinese thought. Chicago: The University of Chicago Press.

Özerdim, M. N. (1945).Büyük Bilgi: Müzik Hakkında Notlar (Great Learning: Notes on Music). Ankara: Milli Eğitim Basımevi. 
Ronan, C. A. (2003). Bilim Tarihi: Dünya Kültürlerinde Bilimin Tarihi ve Gelişmesi (Science: Its History and Development Among World Cultures). Ankara: Tübitak Yayınları.

Sharot, S. (2001). Comparative sociology of world religions: Virtuosi, priests, \& popular religion. New York: New York University Press.

Tarde, G. (1905). Underground man. Connecticut: Hyperion Press Inc..

Tarde, G. (2000). Social laws: An outline of sociology. Kitchener: Batoche Books.

Tarde, G. (2004a). Ekonomik Psikoloji (La psychologie économique). (Ulus Baker Trans.). Ankara: Öteki Yayınevi.

Tarde, G. (2004b). Monadoloji ve Sosyoloji (Monadology and Sociology). (Ulus Baker Trans.). Ankara: Öteki Yayınevi.

Tarde, G.(2012). Monadology and sociology (Theo Lorenc, Ed., Trans.). Melbourne: Re.press.

YAO, X.Z. (2000). Introduction to Confucianism. West Nyack: Cambridge University Press. Retrieved from http://site.ebrary.com/lib/ankarauniv/Doc?id=10073561

Yardımlı, A. (1998). Decartes Söylem-Spinoza İnceleme-Leibniz Monadoloji(Decartes: Discours de la method-Spinoza: Tractatus de Intellectus Emendatione-Leibniz: Monadologie). İstanbul: İdeaYayınları.

Zhongyong中庸 (The doctrine of the mean). (1996). Sishu Yizhu四书译著. Jilin: Jilin Wenshi Chubanshe.

Zuozhuan左转 (The Zuo Commentary) (1996). Shishu Yizhu史书译著. Jilin: Jilin Wenshi Chubanshe.

ZZXS. (1980). Zhongguo Zhexue Shi 中国哲学史 (History of Chinese Philosophy). Beijing: Zhonghua Shuju Chuban. 